\title{
DISTRIBUTION OF MONOSPORASCUS ROOT ROT AND VINE DECLINE DISEASE OF CUCURBITS IN EGYPT \\ El-Desouky, S.M. ${ }^{1}$; M.A. Awad ${ }^{2}$ and, Majdah M.Y. Al-Tuwaijri ${ }^{3}$ 1-Plant Pathology Res. Institute, Agric. Res. Center, 12619 Giza, Egypt 2-Agric. Botany Dept., Fac. of Agric., Minufiya Univ, Shibin el-Kom, Egypt \\ 3-Fac. of Applied Sciences for Girls, Umm Al-Qura Univ., Makkah, KSA
}

\begin{abstract}
Root rot and vine decline (MRR/VD) disease of cucurbits caused by Monosporascus cannonballus is one of the recently described diseases in Egypt. The inciting is a soil borne fungus classified as Ascomycetes fungus named Monosporascus cannonballus Pollack and Uecker belonged to order Sordariales, family Sordariacea. Field and in vitro experiments examined the distribution and pathogenicity of $M$. cannonballus. The disease occurred in Egypt on cultivated cucurbits i.e. cantaloupe (Cucumis melo var. cantulepensis), watermelon (Citrullus lanatus) and cucumber (Cucumis sativus) plants. In three years of disease survey, the disease occurred at 10, 10 and 2 fields of cantaloupe, watermelon and cucumber, respectively during late summer of 2006, 2007 and 2008, which were located at Nubariya (Behaira), Sumosta (Beni Suif), Gamsa (Demietta), Kasassin and Tal ElKaper (Ismailia), Queisna and Sadat city (Minufiya), El-Arish (North Sinai), Salhiya and Abu Kabir (Sharkyia)

Disease progression in different tested cucurbits grown in fields at different localities was not observed until the fruit set stage of plant growth, but rapidly increased at the fruit maturity stage (10 to 14 days pre-harvest) resulting yield loss reached more than $50 \%$. The isolation rate of $M$. cannonballus reached $22.0 \%$ from diseased hosts. In in vitro test, diseased seedlings after one to two weeks of inoculation and perithecia were formed in infected roots 21 days later. Also all tested isolates were pathogenic to all tested cucurbit host plants.

Keywords: cantaloupe, watermelon, cucumber, Monosporascus root rot and vine decline (MRR/VD), Monosporascus cannonballus, distribution.
\end{abstract}

\section{INTRODUCTION}

Cucurbits are considered one of the most important and widely distributed vegetables in Egypt and all over the world. Family Cucurbitaceae consists of approximately 90 Genera, but 3 only are widely grown in Egypt, i.e. Cucumis spp. (cucumber \& melons), Citrullus spp. (watermelon) and Cucurbita spp. (squash \& Pumpkin). They are grown in Egypt at many localities; either in open fields and / or protected cultivations. The cultivated area reached about 250,000 Fadden in 2007.

The first published report of Monosporascus cannonballus came from Arizona in 1970. It was reported as an unknown fungus from rotted secondary roots of cantaloupe plants (Troutman and Matejka 1970). This fungus classified as Ascomycetes fungus named Monosporascus cannonballus Pollack and Uecker (Pollack \& Uecker, 1974). In 1990 the causal agent has been also found (Mertely et al.1991) as a little known, soil borne fungus, $M$. cannonballus and the disease was named Monosporascus 
root-rot and vine decline (MRR/VD). During the recent years, MRR/VD disease was observed on cantaloupe, watermelon and cucumber which grew during the hot weather. Soil borne diseases of cantaloupe, watermelon and cucumber particularly MRR/VD, have been a problem and distributed in many parts of the world. Martyn and Miller (1996) reviewed that, the pathogen is common in hot, semiarid melon and watermelon growing areas of Israel, Japan, Southwestern regions of the United States, Southern Spain, Tunisia, India, Saudi Arabia, Central America, Guatemala, Honduras and Taiwan. The phenomenon of melon and watermelon wilting due to Monosporascus infection is known in many regions around the world and has been referred to as melon collapse (Reuveni et al.,1983; Pivonia et al. 1998; Sarpeleh, 2008), sudden wilt (Eyal and Cohen 1986; Cohen et al, 1996; Pivonia et al. 1997; Pivonia et al. 1998; Edelstein et al. 1999), root rot (Uematsu et al. 1992; Kim et al.,1995), vine decline (Stanghellini et al.,1995; Bruton and Miller, 1997;Cohen et al, 1999), and Monosporascus root rot and vine decline (Mertely et al.,1991; Martyn et al.1994; Wolff, 1995; Martyn and Miller, 1996; Wolff and Miller,1998)

The disease distributed in many parts of the world on different cucurbit hosts i.e. on melon in Japan (Uematsu and Sekiyama, 1990) in Saudi Arabia (Karlatti et al. 1997), in Honduras (Bruton and Miller, 1997) in Brazil (Marinho et al. 2002) in Iran (Sarpeleh 2008), on cantaloupe in Arizona, USA (Stanghellini et al. 1996) on melon, oriental melon, watermelon and cucumber in Korea (Heo et al. 2001a). In Egypt, MRR/VD disease is one of the recently described diseases which reported on diseased plants of cantaloupe and watermelon (El-Desouky and El-Wakil, 2003).

Pathogencity was firstly confirmed in 1985 with isolates from Japan (Uematsu et al. 1985, Uematsu and Sekiyama 1990) and with isolates from USA in 1990 (Mertely et al. 1991). The most recent confirmation of pathogencity was from Saudi Arabia (Karlatti et al. (1997), from Korea Heo et al., 2001a, from Korea Heo et al., 2001a) and from Egypt (El-Desouky and ElWakil, 2003).

The objective of this study was to confirm the root-rot and vine decline disease of cantaloupe, watermelon and cucumber in Egypt, which is caused by $M$. cannonballus. Description of the disease symptoms, Distribution, confirmation of pathogenicity was conducted.

\section{MATERIALS AND METHODS}

\section{Disease survey:}

MRR / VD disease was surveyed in three commercial cucurbits fields belonged to cantaloupe, watermelon and cucumber at ten locations represented seven governorates during the summer seasons of 2006, 2007 and 2008. The locations of the surveyed governorates were: Nubariya (Beheira), El-Kasassin and El-Tal El-Kapeer (Ismailiya), Gamsa (Damietta), Salhiya and Abu Hammad (Sharkiya), El-Arish (North Sinai), Sumosta (Beni Suief) and Queisna \& Sadat city (Minufiya). Five fields represented each location were randomly chosen for inspection and investigation to determine the disease occurrence and percentage of disease incidence. 


\section{Collection of infected specimens:}

Diseased plants of cultivated cucurbits belonged to cantaloupe, watermelon and cucumber showed root-rot and vine decline symptoms were collected for determination the frequency of fungi occurred and associated with diseased roots. They were obtained occasionally over a three-year period of 2006, 2007 and 2008 from fields of many localities in Egypt (Table, 1). Samples were obtained from five fields of each location, where plants were suffered from the disease. The collected samples were brought to the laboratory and then the number of isolated fungi and their frequency was determined. Then, the diseased plants were subjected to the isolation trial. Isolation and identification:

Isolations were also made from 20 symptomatic plants per field, using tissue excised from cortical lesions of tap root and necrotic margins of small, lateral roots. The excised tissue of root were washed with tap water, surface-disinfected in $0.5 \%$ sodium hypochlorite for approximately two minutes and rinsed in sterile distilled water. They were plated on water agar (WA) and incubated at $25^{\circ} \mathrm{C}$. After $3-5$ days of incubation, hyphal tips were transferred to potato dextrose agar (PDA). After 7 days, plates were examined and colonies were identified according to Pollack and Uecker (1974). Isolates were transferred to PDA slants and were kept for the further studies. The Frequencies of isolation of each isolate was recorded based on location.

Inoculum production:

Different isolates of $M$. cannonballus that were isolated from diseased roots of different cucurbit plants grown in investigated localities were used throughout this study. Inoculums were prepared by growing the fungus isolates on PDA plates at $25^{\circ} \mathrm{C}$. When the fungus grew over media in plates, the mycelium was cut to small pieces and used as inoculum (Uematsu et al. 1985 and Cohen et al, 1996).

\section{Pathogenicity test:}

Pathogenicities of different isolates were evaluated in the greenhouse $\left(25-35^{\circ} \mathrm{C}\right)$. They were tested on cantaloupe (Cucumis melo var. cantalupensis cv. Ideal), on watermelon (Citrullus lanatus cv. Aswan) and on cucumber (Cucumis sativus cv. Beit Alpha). The experiments were conducted in $25 \mathrm{~cm}$-diameter pots filled with sandy soil. Inoculum was mixed at the rate of culture on one plate $/ 1 \mathrm{~kg}$ sandy soil. Soil mixed with PDA only used as a check (untreated). Fifty seeds were used for each treatment. Each treatment comprised five replicates.

\section{Disease assessment}

Plants were harvested when reached to fruit maturity and roots were recovered by gentle washing. Roots were rated for disease severity according to Aegerter et al., (2000) as infection Type (IT), where: $0=$ no symptoms, 1 = few lesions (covering $<10 \%$ of root), secondary root rot slight, 2 = rot of secondary roots or lesions covering approximately $25 \%$ of the root, $3=$ lesions covering at least $50 \%$ of the root and dead secondary roots, 4 = general root rot, most of the root affected, also including (pre and post emergence damping - off). Disease severity index (DSI) was recorded according to (Kobriger et al. 1998) as follow: 
Desouky, S.M. et al.

Disease severity index $(\mathrm{DSI})=[\Sigma$ (disease class $\times$ No. plants in class) $\times 100]$ $\div$ (total plants) $\times 4$ ]. Also the number of surviving plants was recorded at the end of the growing period.

Statistical analysis: Data obtained were subjected to the proper statistical analysis for each experiment using the MSTAT statistical software. Comparisons were made following Fishers LSD (0.05).

\section{RESULTS}

\section{Disease symptoms:}

The fungus infects young secondary and tertiary roots of cucurbit plants i.e cantaloupe, watermelon and cucumber early in the season, but the infected plants usually do not develop symptoms till near maturity stage. The fungus colonizes the cortical tissue, ultimately affects the most of the feeder roots. Extensive reddish-brown areas on tap root and some lateral roots appeared and may slough-off as the plant is pulled from the ground. At or near harvest, most of the root system is affected and the vines begin to collapse, beginning with the crown leaves and progressing distally till the entire canopy may collapse, exposing the fruit to intense solar radiation. Lateral roots may bear numerous black perithecia, which contain several black, spherical ascospores. Perithecia often were observed profusely on such secondary and tertiary roots, but rarely on tap roots. The ascus is hyaline and each contains only one ascospore.

\section{Disease survey:}

MRR/VD disease incidence was surveyed on cantaloupe, watermelon and cucumber plants grown in commercial fields at ten locations represented seven governorates during the summer season of 2006, 2007 and 2008. Data in Table (1) showed that the values of the disease incidence during the summer season of 2008 were generally higher than those recorded during summer season of 2006 or 2007. Percentages of the disease incidence (Expressed as DSI) at the different locations varied from 4.00 to $16.33 \%$ (Mean $=9.40 \%$ ) during summer season of 2008. While they were 2.67 to $13.00 \%$ (Mean $=8.73 \%$ ) during summer season of 2007 and from 2.00 to $13.67 \%$ (Mean $=6.94 \%$ ) during summer season of 2006 .

The highest value of mean DSI $(11.00 \%)$ was recorded at Nubariya (Behaira), followed by (10.89\%) at sadat city (Minufiya), $10.78 \%$ at El-Arish (North Sinai), 9.89\% at Salhiya (Sharkiya), 9.78\% at Sumosta (Beni Suif) and $(7.33 \%)$ at Abu Kabir (Sharkyia). The lowest values were recorded (5.00, 5.56, 5.78 and 6.00\%) at El-Tal El-Kapeer, El-Kasassin (Ismailia), Queisna (Minufiya) and at Gamasa (Damietta), respectively. Generally, the disease was recorded on cantaloupe and watermelon at all investigated localities while the disease was recorded on cucumber at Nubariya (Behaira) during late summer of 2008 and at Sadat city (Minufiya) during late summer of 2006 and 2008. 
Table (1): Incidence of Monosporascus root rot / vine decline disease, expressed as disease severity index (DSI), on cantaloupe, watermelon and cucumber in commercial fields at six governorates during late summer seasons of 2006, 2007 and 2008.

\begin{tabular}{|l|l|c|c|c|c|}
\hline \multirow{2}{*}{ Governorate } & \multirow{2}{*}{ Location } & \multicolumn{4}{|c|}{ Late summer season / disease severity index (DSI) } \\
\cline { 3 - 6 } & & $\mathbf{2 0 0 6}$ & $\mathbf{2 0 0 7}$ & $\mathbf{2 0 0 8}$ & Mean \\
\hline \multirow{2}{*}{ Behira } & Nubariya & $4.67^{*}$ & 12.00 & 16.33 & 11.00 \\
\hline Beni Suif & Sumosta & 3.00 & 10.00 & 16.33 & 9.78 \\
\hline Demietta & Gamasa & 7.67 & 5.33 & 5.00 & 6.00 \\
\hline \multirow{2}{*}{ Ismailia } & Kasassin & 5.00 & 3.67 & 8.00 & 5.56 \\
& Elal El-Kapeer & 3.38 & 2.67 & 4.00 & 5.00 \\
\hline Minufiya & Queisna & 5.33 & 8.00 & 4.00 & 5.78 \\
& Sadat city & 10.00 & 9.67 & 13.00 & 10.89 \\
\hline North Sinai & El-Arish & 13.67 & 8.33 & 10.33 & 10.78 \\
\hline \multirow{2}{*}{ Sharkiya } & Salhiya & 9.67 & 13.00 & 7.00 & 9.89 \\
\hline Mean & Abu Kabeer & 2.00 & 11.00 & 10.00 & 7.67 \\
\hline
\end{tabular}

*Each sample belongs to 30 plants obtained from 3 fields (10 plant samples of each cantaloupe, watermelon and cucumber /field).

Table (2): Frequency of incidence of Monosporascus root rot / vine decline disease on different cucurbit plants during 2006, 2007 and 2008 late summer season at different localities in Egypt.

\begin{tabular}{|c|c|c|c|c|c|c|}
\hline \multirow[t]{2}{*}{ Governorate } & \multirow[t]{2}{*}{ Location } & \multirow[t]{2}{*}{ Season } & \multicolumn{4}{|c|}{ Cucurbit crop / disease severity index (DSI) } \\
\hline & & & Cantaloupe & Watermelon & Cucumber & Total \\
\hline Behaira & Nubariya & $\begin{array}{l}2006 \\
2007 \\
2008\end{array}$ & $\begin{array}{c}3.00^{*} \\
7.00 \\
10.33\end{array}$ & $\begin{array}{l}1.67 \\
5.00 \\
4.67\end{array}$ & $\begin{array}{l}0.00 \\
0.00 \\
1.33\end{array}$ & $\begin{array}{l}4.67 \\
12.00 \\
16.33\end{array}$ \\
\hline Beni Suif & Sumosta & $\begin{array}{l}2006 \\
2007 \\
2008\end{array}$ & $\begin{array}{l}2.00 \\
7.00 \\
9.33\end{array}$ & $\begin{array}{l}1.00 \\
3.00 \\
7.00\end{array}$ & $\begin{array}{l}0.00 \\
0.00 \\
0.00\end{array}$ & $\begin{array}{l}3.00 \\
10.00 \\
16.33\end{array}$ \\
\hline Demietta & Gamasa & $\begin{array}{l}2006 \\
2007 \\
2008\end{array}$ & $\begin{array}{l}3.00 \\
2.33 \\
2.00\end{array}$ & $\begin{array}{l}4.67 \\
3.00 \\
3.00\end{array}$ & $\begin{array}{l}0.00 \\
0.00 \\
0.00\end{array}$ & $\begin{array}{l}7.67 \\
5.33 \\
5.00\end{array}$ \\
\hline Ismailia & Kassasin & $\begin{array}{l}2006 \\
2007 \\
2008\end{array}$ & $\begin{array}{l}3.00 \\
2.67 \\
6.00\end{array}$ & $\begin{array}{l}2.00 \\
1.00 \\
2.00\end{array}$ & $\begin{array}{l}0.00 \\
0.00 \\
0.00\end{array}$ & $\begin{array}{l}5.00 \\
3.67 \\
8.00\end{array}$ \\
\hline & $\begin{array}{l}\text { El-Tal } \\
\text { El-Kapeer }\end{array}$ & $\begin{array}{l}2006 \\
2007 \\
2008\end{array}$ & $\begin{array}{l}3.33 \\
2.33 \\
3.00\end{array}$ & $\begin{array}{l}5.00 \\
0.33 \\
1.00\end{array}$ & $\begin{array}{l}0.00 \\
0.00 \\
0.00\end{array}$ & $\begin{array}{l}8.33 \\
2.67 \\
4.00\end{array}$ \\
\hline Minufiya & Queisna & $\begin{array}{l}2006 \\
2007 \\
2008\end{array}$ & $\begin{array}{l}1.33 \\
3.00 \\
1.00\end{array}$ & $\begin{array}{l}4.00 \\
5.00 \\
3.00\end{array}$ & $\begin{array}{l}0.00 \\
0.00 \\
0.00\end{array}$ & $\begin{array}{l}5.33 \\
8.00 \\
4.00 \\
\end{array}$ \\
\hline & Sadat city & $\begin{array}{l}2006 \\
2007 \\
2008\end{array}$ & $\begin{array}{l}5.00 \\
5.67 \\
8.00\end{array}$ & $\begin{array}{l}4.00 \\
4.00 \\
3.00\end{array}$ & $\begin{array}{l}1.00 \\
0.00 \\
2.00\end{array}$ & $\begin{array}{c}10.00 \\
9.67 \\
13.00\end{array}$ \\
\hline North Sinai & El-Arish & $\begin{array}{l}2006 \\
2007 \\
2008\end{array}$ & $\begin{array}{l}8.00 \\
5.00 \\
6.33\end{array}$ & $\begin{array}{l}5.67 \\
3.33 \\
4.00\end{array}$ & $\begin{array}{l}0.00 \\
0.00 \\
0.00\end{array}$ & $\begin{array}{c}13.67 \\
8.33 \\
10.33\end{array}$ \\
\hline Sharkiya & Salhiya & $\begin{array}{l}2006 \\
2007 \\
2008 \\
\end{array}$ & $\begin{array}{l}6.67 \\
8.00 \\
4.00\end{array}$ & $\begin{array}{l}4.00 \\
5.00 \\
3.00\end{array}$ & $\begin{array}{l}0.00 \\
0.00 \\
0.00 \\
\end{array}$ & $\begin{array}{c}9.67 \\
13.00 \\
7.00 \\
\end{array}$ \\
\hline & Abu Kabeer & $\begin{array}{l}2006 \\
2007 \\
2008 \\
\end{array}$ & $\begin{array}{l}1.00 \\
7.00 \\
6.00 \\
\end{array}$ & $\begin{array}{l}1.00 \\
4.00 \\
4.00 \\
\end{array}$ & $\begin{array}{l}0.00 \\
0.00 \\
0.00 \\
\end{array}$ & $\begin{array}{l}2.00 \\
11.00 \\
10.00 \\
\end{array}$ \\
\hline
\end{tabular}

*Each sample belongs to 30 plants obtained from 3 fields (10 plant samples of each cantaloupe, watermelon and cucumber /field). 
Desouky, S.M. et al.

Data presented in Table (2) showed the frequency of incidence of MRR/VD disease on different cucurbit plants i.e. cantaloupe, watermelon and cucumber during late summer season of 2006, 2007 and 2008 at different localities in Egypt.

Data also clear that the values of the mean DSI varied on different cucurbit host plants. The highest value of mean DSI was recorded on cantaloupe plants and reached to $10.33 \%$ followed by watermelon which recorded $7.00 \%$ while the lowest values were recorded on cucumber which ranged from 1 to $2 \%$.

In the present work, M. cannonballus caused severe root-rot of cantaloupe, watermelon and cucumber in different growing areas in Egypt. The fungus was isolated from diseased cantaloupe, watermelon and cucumber plants in low frequencies at few fields in survey during hot weather.

Percentage of isolation frequency of $M$. cannonballus from cantaloupe, watermelon and cucumber were obtained at different localities in Egypt during late summer season of 2006, 2007 and 2008.

Table (3): Isolation frequency \% of $M$. cannonballus from cantaloupe, watermelon and cucumber at different localities in Egypt during late summer of 2006, 2007 and 2008.

\begin{tabular}{|l|l|c|c|c|}
\hline \multirow{2}{*}{ Governorate } & Localition & \multicolumn{2}{|c|}{ Cucurbit crop / Frequency of pathogen isolate \% } \\
\cline { 3 - 5 } & & Cantaloupe & Watermelon & Cucumber \\
\hline Behaira & Nubariya & $22.00^{\star}$ & 16.33 & 4.67 \\
\hline Beni Suif & Sumosta & 12.00 & 8.67 & 0.00 \\
\hline Demietta & Gamasa & 12.00 & 10.00 & 0.00 \\
\hline Ismailia & Kassasin & 17.33 & 11.67 & 0.00 \\
& Tal El-Kaper & 10.67 & 7.33 & 0.00 \\
\hline Minufiya & Queisna & 13.00 & 11.00 & 0.00 \\
& Sadat city & 18.33 & 15.00 & 2.67 \\
\hline North Sinai & El-Arish & 11.67 & 8.00 & 0.00 \\
\hline Sharkita & Salhiya & 16.00 & 6.33 & 0.00 \\
& Abu Kabir & 18.00 & 8.67 & 0.00 \\
\hline
\end{tabular}

* Mean of thirty symptomatic plants of each field which taken for isolation of the pathogen

Data presented in Table (3) show that, the percentage of isolation varied according cucurbit crop grown in different locations. They were ranged from 10.67 to $22.00 \%$ of $M$. cannonballus isolates obtained from infected cantaloupe roots. While, isolation varied between 7.33 to $16.33 \%$ of infected watermelon roots. However, isolation from infected cucumber roots was recorded 4.67 and $2.67 \%$ at Nubariya (Behaira) and Sadat city (Minufiya), respectively.

The highest frequencies of $M$. cannonballus isolation were recorded at Nubariya (Behaira) and Sadat city (Minufiya) within different three investigated cucurbit host plants.

\section{Pathogenicity test:}

Pathogenic ability of different $M$. cannonballus isolates was conducted in order to confirm their virulence and to define the most aggressive isolates causing serious damage on cantaloupe, watermelon and cucumber plants. Ten isolates were selected out of twenty two fungal isolates that obtained. Data given in Table (4) show that isolates of the studied fungus 
were chosen according to their frequency as five isolates of $M$. cannonballus from cantaloupe (Nos. 1-5), three isolates from watermelon (Nos. 6-8) and two from cucumber (Nos. 9-10). They were chosen to perform their pathogenic ability on different cucurbit host plants.

Data presented in Table (4) indicate that all the tested isolates were pathogenic on cantaloupe, watermelon and cucumber as they significantly increased MRR / VD severities on different cucurbit host plants. Also it showed that $M$. cannonballus (isolate No. 5) were the most aggressive isolate than the other isolates of this fungus with significant differences between this isolate and the others.

Table (4): Virulence of Monosporascus cannonballus isolates obtained from rotten roots of cucurbit plants colleted from different localities in Egypt under greenhouse conditions.

\begin{tabular}{|c|c|c|c|}
\hline \multirow{2}{*}{ Fungus / Isolates } & \multicolumn{3}{|c|}{ Cucurbit crop / Mean disease severity index (DSI) } \\
\hline & $\begin{array}{c}\text { Cantaloupe } \\
\text { cv. Ideal }\end{array}$ & $\begin{array}{c}\text { Watermelon } \\
\text { cv. Aswan }\end{array}$ & $\begin{array}{c}\text { Cucumber } \\
\text { cv. Beit Alpha }\end{array}$ \\
\hline \begin{tabular}{|ll}
$M$. & cannonball \\
2 & Isolate 1 \\
3 & \\
4 & \\
5 & \\
5 & \\
7 & \\
8 & \\
9 & \\
10 & \\
& \\
Control & \\
\end{tabular} & $\begin{array}{l}39.20^{*} \\
33.40 \\
36.20 \\
39.00 \\
43.00 \\
31.40 \\
28.80 \\
26.20 \\
29.40 \\
33.00 \\
00.00\end{array}$ & $\begin{array}{l}28.00 \\
21.40 \\
25.00 \\
20.20 \\
29.00 \\
24.60 \\
21.20 \\
18.40 \\
20.00 \\
19.00 \\
00.80\end{array}$ & $\begin{array}{l}15.60 \\
12.00 \\
09.20 \\
12.00 \\
13.00 \\
08.60 \\
12.00 \\
11.80 \\
10.00 \\
11.20 \\
00.60\end{array}$ \\
\hline L. S. D. at $5 \%$ & 00.44 & 00.69 & 00.53 \\
\hline
\end{tabular}

*Mean of five replicates.

Percentages data were arcsine-transformed before carrying out the analysis of variance.

This aggressive isolate show the highest significant percentages disease severity index (43.0, 29.0 and $13.0 \%$ ) on cantaloupe, watermelon and cucumber, respectively. This virulent isolate No 5 was followed by isolates (Nos.1, 4, 2 and 10) in their pathogenic ability to evaluate their potential in causing MRR /VD disease symptoms. The third rank include isolates (Nos.3, 6, 7, 8 and 9) in this respect.

\section{DISCUSSION}

Firstly, the periodical survey of cucurbit plants for different diseases incidence revealed that MRR / VD disease on cantaloupe and watermelon was recently observed in Egypt. The disease was firstly found on cantaloupe plants of Ideal and Galia cultivars in a commercial field at Nubariya (Behaira) and at El-Arish (North Sinai). It was also found on watermelon of cultivar Giza-1 at Gamasa (Damietta) in late summer season during the period of 1999 to 2001 (El-Desouky and El-Wakil 2003).

In this investigation, infected cucurbit plants i.e. cantaloupe, watermelon and cucumber usually do not develop symptoms till near harvest 
time. Sometimes, the aboveground of disease symptoms is a gradual yellowing and dieback of the older leaves as the plants set fruit.

Foliar deterioration progressing distally and advances to young leaves at the harvest period. Affected plants suddenly wilt and eventually die, prematurely showing the vine decline symptoms. The underground symptoms appear as extensive areas of tap roots and some lateral roots are necrotic, and may slough off as the plant is pulled from the ground.

In recent years, MRR/VD disease on cantaloupe and watermelon was first found on cantaloupe plants of Ideal cultivar in a commercial field at Nubariya (Behira Governorate) during late summer season of 1999 with disease incidence varied from 27.25 to $85 \%$. The disease was also found on watermelon of cultivar Giza-1 at Gamasa (Damietta Governorate) during summer season of 2000 with disease incidence from 57.25 to $88.25 \%$. Later, the disease was also found on cantaloupe plants cv. Galia at El-Arish (North Sinai Governorate) during late summer season of 2001 with disease incidence ranged from 38.25 to $78.25 \%$ (El-Desouky and El-Wakil 2003)

The disease is primarily appearing as a problem on sandy soils in Egypt. During this study, the fungus $M$. cannonballus was isolated from ten localities in Egypt where cantaloupe, watermelon and cucumber grown in a sandy or sandy loamy soils. The fungus is indigenous to the soil and populations build up with continuous cultivation of cucurbit hosts, particularly cantaloupe, watermelon and cucumber. In USA, during 1991, Monosporascus was discovered at Texas on the farms on which the soil texture is similar in $\mathrm{pH}$ (7.7 to 7.8$)$ and soil salt content, suggesting that the fungus may prefer or tolerate alkaline and saline condition (Mertely et al. (1991).

The fungus was isolated from diseased plants in low frequencies at few fields in survey during hot weather. Due to thermophillic nature of $M$. cannonballus, it appears to be adapted to hot, semiarid climate with soil tend to be saline and alkaline and may be more active as a pathogen (Martyn and Miller, 1996 and Stanghellini et al. 1996).

Pathogenicity test was conducted in order to found the ability of $M$. cannonballus isolated from diseased plants to MRR / VD syndrome of cantaloupe, watermelon and cucumber in the greenhouse. Ten isolates of $M$. cannonballus were chosen for pathogenicity test. All the tested isolates were pathogenic on cantaloupe, watermelon and cucumber since they significantly increased root diseases severity index. M. cannonballus (isolate No. 5) was the most aggressive isolate than the others with significant differences between them. Their importance seems to be in their ability to co-colonize the roots of different cucurbit host plants and to induce a greater disease contribution extent. In addition, a variety of organisms has been reported as causal agents of MRR / VD disease in various regions in the world including M. cannonballus (Uematsu et al., 1992, Martyn et al. 1994, Miller et al. 1995 and Martyn and Miller, 1996). It is possible that all of these organisms act similarly by suppressing the root system, and finally affecting the balance between sink and source, especially during the period of fruit maturation.

The rapid development of the disease could be attributed to the reduction of high water demand by plants during later stages of plant 
development that makes the uptake and water flow through the roots is constrained. The disease may do the most damage to thin roots, as although they make up a small percentage of the root mass, they contribute substantially to plant water uptake. Infected plants showed reduction in root growth, indicating that vine collapse is due in part to the negative effects on growth and root system size (Pivonia et al., 2002).

\section{REFERENCES}

Aegerter, B.J., Gordon, T.R. and Davis, R. M. 2000. Occurrence and pathogenicity of fungi associated with melon root rot and vine decline in California. Plant Dis., 84: 224-230.

Bruton, B.D. and Miller, M.E. 1997. Occurrence of vine decline diseases of melons in Honduras. Plant Dis., 81 (6): 696.

Cohen, R., Elkind, Y., Burger, Y., Offenbach, R., and Nerson, H. 1996. Variation in the response of melon genotypes to sudden wilt. Euphytica, 87: 91 - 95.

Cohen, R., Pivonia, S., Shtienberg, D., Edelstein, M., Raz, D., Gerstl, Z. and Katan, J. 1999. The efficiency of fluazinam in suppression of Monosporascus cannonballus, the causal agent of vine decline of melons. Plant Dis., 83: 1137 - 1141.

Edelstein, M., Cohen, R., Burger, Y., Shriber, S., Pivonia and Shtienberg, D. 1999. Integrated management of sudden wilt in melons, caused by Monosporascus cannonballus, using grafting and reduced rates of methyl bromide. Plant Dis. 83: $1142-111145$.

El-Desouky, S.M. and El-Wakil, A.A. 2003. Occurrence of Monosporascus Root Rot and Vine Decline of Cantaloupe and Watermelon in Egypt. Egypt. J. of Phytopath.,

Eyal, H. and Cohen, Y. 1986. Sudden wilt in muskmelon: A Continuing Callenge. (Abstr.). Phytoparasitica, 14: 251.

Heo, N.Y., Ryu, K.Y., Hyun, I.H. and Kwon, J.H. 2001a. Occurrence and distribution of Monosporascus root rot and pathogenicity of Monosporascus cannonballus on Cucurbitaceae plants. Research in Plant Disease, 7 (1): 11-15.

Heo, N.Y., Ryu, K.Y. and Lee, Y.B. 2001b. Cultural characteristics and ascospore density in soil of Monosporascus cannonballus on Cucurbitaceae plants. Research in Plant Disease, 7 (1): 16-19.

Karlatti, R.S., Abdeen, F.M. and Al-Fehaid, M.S. 1997. First report of Monosporascus cannonballus on melons in Saudi Arabia. PlantDisease., 81: 10, 1215.

Kim, D. H., Rasmussen, S. L., and Stanghellini, M.E. 1995. Monosporascus cannonballus root rot of muskmelon: Root infection and symptom development in relation to soil temperature. (Abstr.) Phytopathology, 85: 1195.

Kobriger, K. M.; Hagedorn, D J. and Stevenson, W. R.(1998). Analysis of the snap bean root rot potential of Wisconsin fields. Wisconsin extension puplications, No. A3242. 
Marinho, R.E.M., Sales-Junior, R., Maracaja, P.B., Silva, G.F., Costa, F.M. and Silva, E. (2002). Identification of the mycoflora associated to melon root system in the States of Rio Grande do Norte and Ceara. Caatinga, 15 (1-2): 25-28.

Martyn, R.D. and Miller, M.E. 1996. Monosporascus root rot and vine decline: an emerging disease of melons melons worldwide. Plant Dis. 80: 716725.

Martyn, R.D., Lovic, R.B. and Miller, M.E. 1994. Monosporascus root rot/vine decline of melons - a case study. G. Lesser \& J. Dunlap et al.(eds.), Cucurbitaceae' 94: 36-43. (C) 1995 Gateway Printing, Printed in the U.S.A.

Mertely, J.C., Martyne, R.D., Miller, M.E. and Bruton, B.D. 1991. Role of Monosporascus cannonballus and other fungi in a root rot / vine decline disease of muskmelon. Plant Dis., 75: 1133-1137.

Miller, M. E., Martyn, R. D., Lovic, B. R., and Bruton, B. D. 1995. An overview of vine decline diseases in melons. Pages 31-35 In: Proc. Cucurbitaceae 94: Evaluation and Enhancement of Cucurbit Germplasm. G. E. Lester and J. R. Dunlap, eds. Gateway Printing, Edinburgh, TX.

Pivonia, S., Cohen R., Kafkafi, U., Ben Ze'ev, I.S. and katan, J. 1997. Sudden wilt of melons in southern Israel: Fungal agents and relationship with plant development. Plant Dis. 81: 1264 - 1268.

Pivonia, S., Kigel, J., Cohen, R. and Katan, J. 1998. The effect of fruit load on the transpiration rate and plant collapse in melon (Cucumis melo L.). infected with Monosporascus cannonballus. Pages 217 - 220 in: Cucurbitaceae 98. Evaluation and Enhancement of Cucurbit Germplasm. D. McCreight, ed. ASHS, Alexandria, VA.

Pivonia, S., Cohen, R., Kigel, J., and Katan, J. 2002. The effect of soil temperature on disease development in melon plants infected by Monosporascus cannonballus. Plant Pathology 51: 472-479.

Pollack, F. G. and Uecker, F.A. 1974. Monosporascus cannonballus an unusual ascomycete in cantaloupe roots. Mycologia, 66: 346-349.

Reuveni, R., Krikun, J. and Shani, U. 1983. The role of Monosporascus eutyboides in a collapse of melon plants in an arid area of Israel. Phytopathology, 73: $1223-1226$.

Sarpeleh A. 2008. The role of Monosporascus cannonballus in melon collapse in Iran. Australasian Plant Disease Notes, 3, 162-164

Stanghellini, M. E., Rasmussen, S. L., Kim, D. H. and Oebker, N. 1995. Vinedecline of melons caused by Monosporascus cannonballus in Arizona: Epidemiology and cultivar susceptibility. Pages 71-80 In: Vegetable Report, College of Agriculture Series P-100. University of Arizona, Tucson.

Stanghellini, M.E., Kim, D.H. and Rasmussen, S.L. 1996. Ascospores of Monosporascus cannonballus : Germination and distributionin cultivated and desert soils in Arizona. Phytopathology, 86:509-514.

Troutman, J. and Matejka, J.C. 1970. Three fungi associated with cantaloupe roots in Arizona. Phytopathology, 60: 1317. 
Uematsu, S., Onog, S. and Watanabe, T. 1985. Pathogenicity of Monosporascus cannonballus Pollack \& Uecker in relation to melon root rot in Japan. Ann. Phytopath. Soc. Japan, 51: 272-276. (in Japanese).

Uematsu, S. and Sekiyama, K. 1990. Comparison of morphological characteristics and pathogenicity of Monosporascus cannonballus Pollack and Uecker collected in Japan, distribution in melon plants with root rot symptoms and survival in soils under laboratory conditions. Soil-Microorganisms., No. 35: 7-12.

Uematsu, S., Hirota, K., Shruishi, T., Ooizumi, T., Sokiyama, K. Ishikura, I. and Edagowa, Y 1992. Monosporascus root rot on bottle gourd stock of watermelon caused Monosporascus cannonballus. Ann. Phytopatholo. Soc. Japan, 8: $345-359$.

Wolff, D. W. 1995. Fruit load affects Monosporascus root rot / vine decline symptoms expression. Pages 87 - 88 In: Melon Production System in South Texas. M.E. Miller, ed. Ann.Res. Rep. Texas Agricultural Experiment Station, Weslaco, TX.

Wolff, D. W. and Miller, M.E. 1998. Tolerance to Monosporascus root rot and vine decline in melon (Cucumis melo L.) germplasm. HortScience, 33: $287-290$.

\footnotetext{
انتشار مرض عفن الجذور وتهدل العرش على القرعيات في مصر

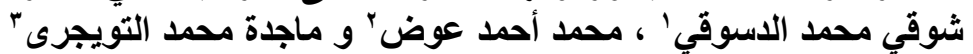

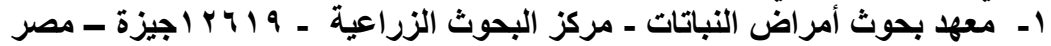

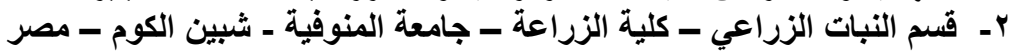
بـ كلية العلوم التطبيقيةً للطالبات- جامعة أم القرى ـ مكة المكرمة ـ المملكة العربية السعودية

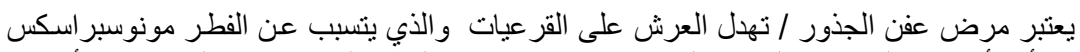

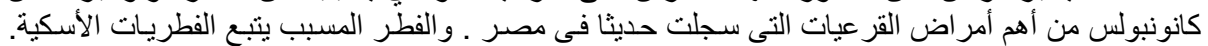

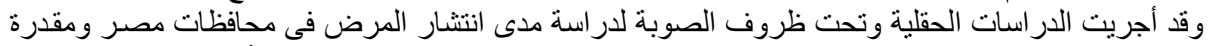

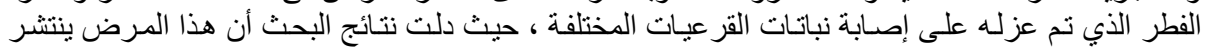

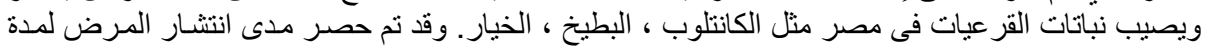

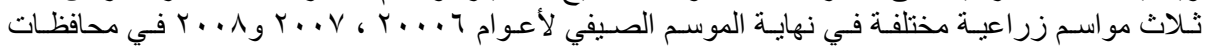

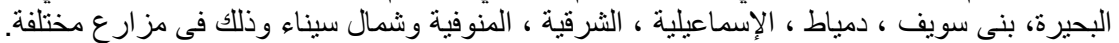

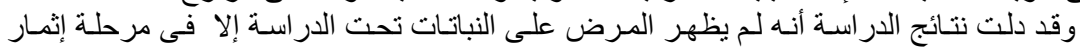

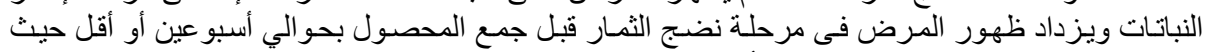

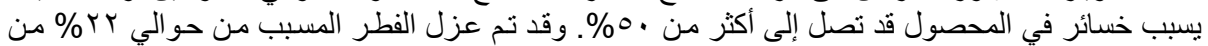

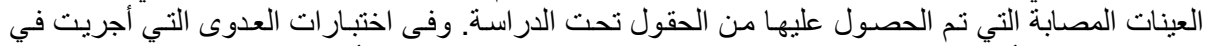

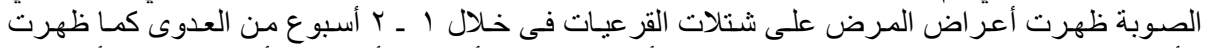

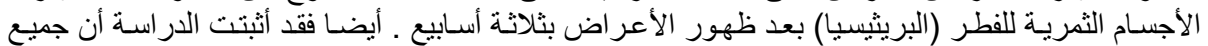

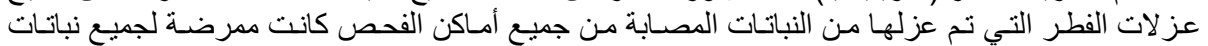
القر عيات تحت الاختبار في الصوبة .
} 